\title{
Production and quality testing of fuel briquettes made from pongamia and tamarind shell
}

\author{
SANTHOSH UJJINAPPA $^{1, *}$ and L K SREEPATHI ${ }^{2}$ \\ ${ }^{1}$ Department of Mechanical Engineering, AMC Engineering College, Bangalore 560083, India \\ ${ }^{2}$ Department of Mechanical Engineering, Jawaharlal Nehru National College of Engineering, \\ Shivamogga 577204, India \\ e-mail: santhoshujjinappa1986@gmail.com
}

MS received 27 February 2017; revised 27 December 2017; accepted 18 January 2018; published online 13 April 2018

\begin{abstract}
Biomass is receiving greater attention, especially in developed countries, mostly as a means of reducing greenhouse gas emissions, increasing energy supply security and decreasing their heavy reliance on imported fossil fuels. However, the low bulk density of biomass is the major limitation in its usage but briquetting overcomes this limitation. This research was carried out to identify the optimum blending ratio for solid fuel briquettes produced by pongamia (Pongamia pinnata) shell (PS) and tamarind (Tamarindus indica) shell (TS) with pongamia cake (PC) $(0,10,20,30 \%)$ as an additive. The cylindrical briquettes were produced with diameter of $3.6 \mathrm{~cm}$ and length of 4.5 to $5.5 \mathrm{~cm}$ at a pressure of 100, 150 and $200 \mathrm{MPa}$. The produced briquettes were evaluated for different briquette properties like compressed density, relaxed density, relaxation ratio, compressive strength and shattering index. The results indicated that the use of pongamia cake creates an adverse effect on the properties of briquettes and hence use of pongamia cake as an additive is not recommended. Briquettes produced with blending ratio of PS:TS:PC $=60: 40: 00$ at $200 \mathrm{MPa}$ have better quality and met the briquette standards for commercial use. The proximate analysis, the ultimate analysis and the calorific value of briquettes produced with blending ratio of PS:TS:PC $=60: 40: 00$ at $200 \mathrm{MPa}$ were conducted and the results indicated that overall combustion properties of the briquettes were improved than the original raw materials; and better than the agro waste briquettes. Thus, this work proved that the blending of PS and TS gives better quality briquettes which can be used as fuel in several applications.
\end{abstract}

Keywords. Biomass; briquette; pongamia shell; tamarind shell; pongamia cake.

\section{Introduction}

In the last decades, the problem of $\mathrm{CO}_{2}$ emission in to the atmosphere has driven an increasing use of biomass fuels in addition to conventional fuels in power generating industries [1]. Direct use of agricultural wastes as solid fuel is often difficult due to their varied physical and combustion characteristics. The process of compaction of wastes into a product of higher density than the original raw material is known as densification [2]. Briquetting is a compacting or densification process to increase the low bulk density of biomass to high density (from $150-200 \mathrm{~kg} / \mathrm{m}^{3}$ to $900-1300$ $\mathrm{kg} / \mathrm{m}^{3}$ ) [3]. The production of biodiesel will provide new fuel resources to the small and middle scale industries worldwide and it could provide a direction for a cost effective alternative fuel [4]. In India, currently, $611 \mathrm{M}$ tons/year of agricultural field wastes are generated of which $158 \mathrm{M}$ tons $(25 \%)$ can be considered unutilized based on current utilization patterns and thus are potentially

*For correspondence available for a bio-based industry [5]. Biodiesel is a renewable fuel mainly produced from edible and non-edible oil seeds. India depends on other countries to fulfill its edible oil demand and hence the use of same for biodiesel is impractical. Therefore, the focus needs to be shifted to nonedible oilseed plants available in India. In India, Pongamia pinnata is one of the promising and potential non-edible oilseed plants having an annual production of 200 thousand tons [6]. With the calorific value of about $16.5 \mathrm{MJ} / \mathrm{kg}$ and the presumed availability (estimated as $40 \mathrm{wt} . \%$ of total Pongamia pinnata mass) of Pongamia pinnata shells, the energy potential of this biomass residue in India can be roughly estimated to be $1320 \mathrm{TJ}$ per year. According to Indian horticulture statistics 2015, the annual production of tamarind fruits in India is 188 thousand tons [7]. With the calorific value of about $16 \mathrm{MJ} / \mathrm{kg}$ and the presumed availability (estimated as $15 \mathrm{wt} . \%$ of total fruit mass) of tamarind shells, the energy potential of this biomass residue in India can be roughly estimated to be $450 \mathrm{TJ}$ per year. As with many other shell-type biomasses exhibiting good combustion properties, tamarind shells can be considered as 
potential fuels for small-scale heat and power plants [8]. However, the aim of the present study is to utilize the byproducts of biodiesel along with agro residues to prepare biomass briquettes and to identify the different briquetting parameters such as compressed density, relaxed density, relaxation ratio, shattering index, compressive strength, and combustion characteristics. Therefore, pongamia shell and tamarind shell were used for production of fuel briquettes by adding pongamia cake as an additive in different ratios.

\section{Materials and methods}

\subsection{Material selection and preparation}

In order to address the transportation fuel scarcity, many countries have taken up large scale production of biodiesel using non edible oil seeds. The cost of biodiesel can be reduced to a great extent by adding value to the by-products like seed shell and cake. In India, significant amount of biodiesel is produced using pongamia and its by-products (pongamia seed shell and pongamia cake) are selected as main raw materials for this study. The quality of the fuel plays an important role in combustion process and it can be analyzed by proximate and ultimate analysis. The analysis of Pongamia shell (PS), Tamarind shell (TS) and Pongamia cake (PC) are shown in table 1. It is observed that all the parameters of proximate and ultimate analysis of PS and TS were very close to each other except the amount of nitrogen was more in TS. It is noted that the nitrogen content in fuel does not contribute towards combustion. As the nitrogen content in PS is low, blending of PS and TS would reduce the nitrogen fraction in the briquette and $\mathrm{PC}$ was selected as a binder. Hence, PS and TS were selected as raw materials for the production of briquettes. Further, the mixing proportions of the additives were varied as S1 = PS:TS:PC = 60:40:00, S2 = PS:TS:PC = 60:30:10, S3 = PS:TS:PC = 60:20:20 and S4 = PS:TS:PC = 60:10:30.

Table 1. Proximate and ultimate analysis of raw materials.

\begin{tabular}{lccc}
\hline Property & $\begin{array}{c}\text { Pongamia } \\
\text { shell (PS) }\end{array}$ & $\begin{array}{c}\text { Tamarind } \\
\text { shell (TS) }\end{array}$ & $\begin{array}{c}\text { Pongamia } \\
\text { cake (PC) }\end{array}$ \\
\hline Proximate analysis (on as received basis, & wt.\%) & \\
Moisture & 11.61 & 8.44 & 12.00 \\
Volatile matter & 70.83 & 68.56 & 71.21 \\
Fixed carbon & 11.86 & 13.44 & 11.71 \\
Ash & 5.70 & 9.56 & 5.08 \\
Ultimate analysis (on dry and ash-free basis, wt.\%) & \\
C & 46.02 & 45.00 & 47.11 \\
H & 5.58 & 5.73 & 5.63 \\
N & 0.23 & 5.14 & 0.27 \\
O & 42.46 & 44.13 & 41.91 \\
Calorific value (MJ/kg) & 16.81 & 16.30 & 17.65 \\
Reference & {$[9]$} & {$[10]$} & {$[11]$} \\
\hline
\end{tabular}

The raw materials pongamia shell and cake were collected from district bio-energy information and demonstration center, JNN College of Engineering, Shimoga, Karnataka; and tamarind shell was collected from local village near Davangere, Karnataka (figure 1). The raw materials were sun-dried to remove moisture and crushed in a hammer mill. The ground raw materials were sieved with an opening of $1.2 \mathrm{~mm}$.

\subsection{Methods}

Briquettes were produced using universal testing machine (UTM) with the maximum capacity of 100 ton at Mechanical Engineering Department, AMC Engineering College, Bangalore. The cylindrical briquettes were produced using briquetting die with an inner diameter of 36 $\mathrm{mm}$ and a height of $120 \mathrm{~mm}$. Each sample was filled into the die with a known weight of $60 \mathrm{~g}$ and briquettes were produced under different pressures of 100, 150 and 200 $\mathrm{MPa}$ with a dwell time of $60 \mathrm{~s}$. Produced briquettes at different pressures (figure 2) were kept for 7 days in ambient condition for observation before analyzing.

In order to use briquette as fuel, it should meet certain desirable property values and methods of determining the property values are discussed below. The compressed density, relaxed density, relaxation ratio, and shattering index of briquette were calculated at AMC Engineering College, Bangalore, Karnataka and compressive strength was calculated at Bapuji Institute of Engineering and Technology, Davangere, Karnataka.

Relaxation ratio describes the stability of the briquettes after ejection from the mould, which is the ratio of compressed density to relaxed density of briquettes. The compressed density of the briquettes was determined immediately after ejection from the die as a ratio of measured mass over calculated volume [12]. Relaxed density (RD) of the briquettes was determined 30 days after removal from the press in accordance with [13].

Shattering index/Durability index is a parameter which indicates the durability of briquettes during storage, handling and transportation. Briquettes shattering index was measured according to ASTM D440-86 [14] of drop shatter developed for coal. The test was conducted after two weeks of briquettes samples formation.

Compressive strength is the maximum crushing load a briquette can withstand before cracking or breaking. Compressive strength of briquettes was determined in accordance with ASTM D2166-85 [15] using an instron universal strength testing machine with a load cell capacity of $500 \mathrm{~kg}$ and a cross-head speed was $0.305 \mathrm{~mm} / \mathrm{min}$.

Combustion characteristics such as the proximate analysis were estimated according to IS:1350 [16], (Part-I, 1984), the ultimate analysis were estimated according to Indian Standard (Determination of Sulphur, IS:1350 [16], Part-III, 1969; Determination of Carbon and Hydrogen, IS:1350 [16], Part-IV/Sec1, 1974; Determination of 

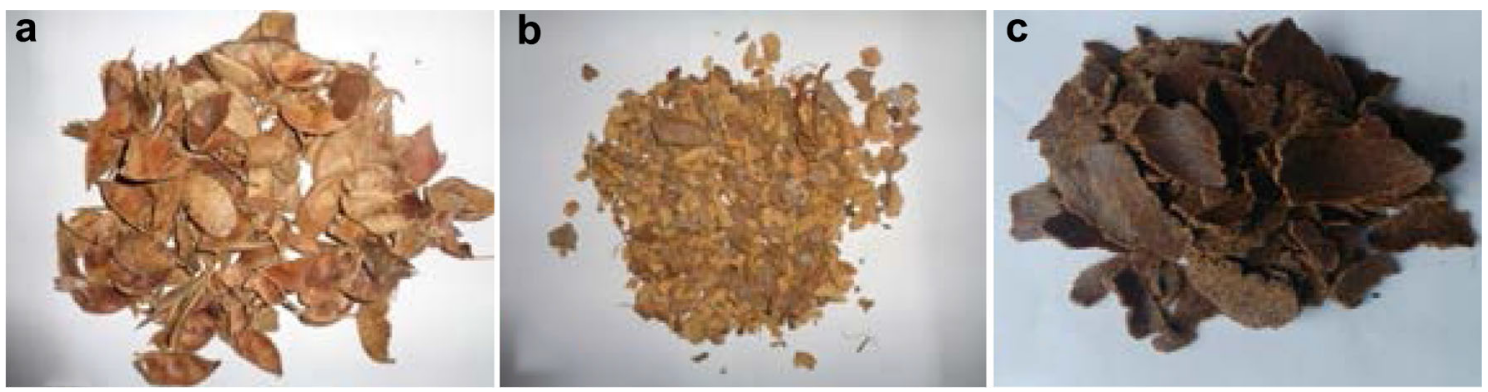

Figure 1. (a) Pongamia shell, (b) Tamarind shell and (c) Pongamia cake.
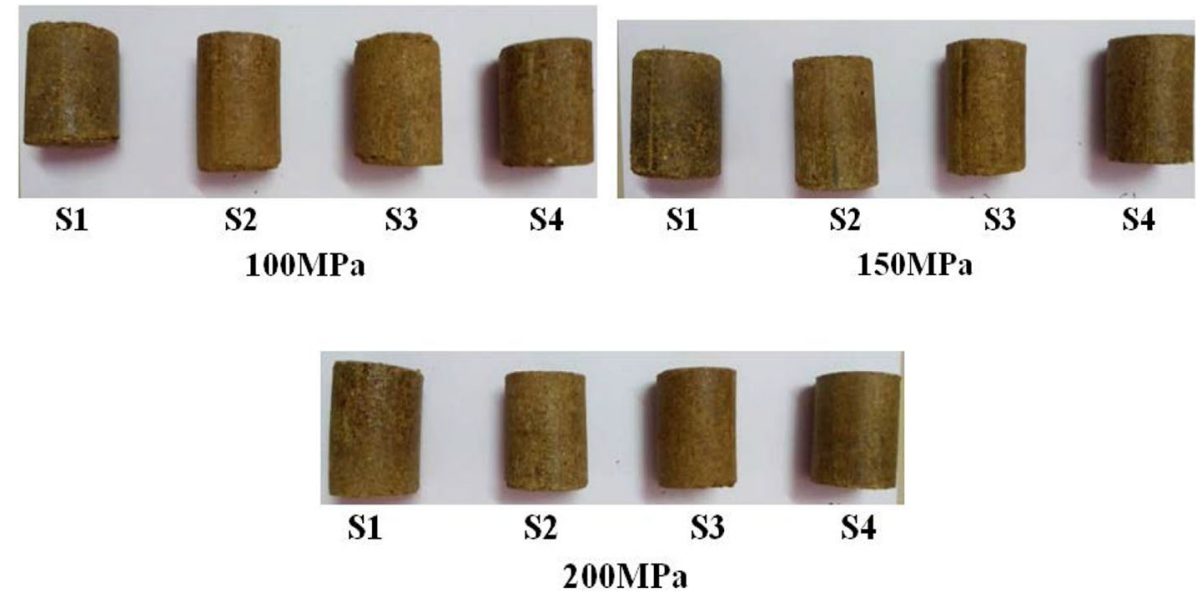

Figure 2. Briquettes produced at different pressure.

Nitrogen, IS:1350 [16], Part-IV/Sec 2, 1975) and the calorific value were estimated according to IS:1350 [16], (Part-II, 1970) which identifies the quality of fuel. Combustion characteristic was determined at Sigma Test and Research Center, Delhi.

\section{Results and discussions}

Various tests were conducted to examine the properties of briquettes. Considerable variation was observed in properties of briquettes produced at different pressures and different binder fractions. The effect of pressure and binder fraction on the properties of briquettes were discussed in section 3.1 and the combustion characteristics were discussed in section 3.2 .

\subsection{The effect of pressure and binder fraction on the properties of briquettes}

Density is an important parameter in briquetting. The higher the density, the higher is the energy/volume ratio. The compressed density is the density of the briquette measured immediately after obtaining the briquette from the briquetting die. Figure 3 decribes the relationship between compressed density and pressure for different samples. The results show that, as the pressure increased, compressed density increased and as binder percentage increased, the compressed density also increased. The compressed density varies from 1026 to $1108 \mathrm{~kg} / \mathrm{m}^{3}$ for $\mathrm{S} 1$, 1049 to $1147 \mathrm{~kg} / \mathrm{m}^{3}$ for $\mathrm{S} 2,1067$ to $1174 \mathrm{~kg} / \mathrm{m}^{3}$ for $\mathrm{S} 3$, while 1142 to $1202 \mathrm{~kg} / \mathrm{m}^{3}$ for $\mathrm{S} 4$. The compressed density increased from 1026 to $1202 \mathrm{~kg} / \mathrm{m}^{3}$ as the binder (PC) quantity increased from 0 to $30 \%$. The lowest compressed density was observed for $0 \%$ binder (S1), and at $100 \mathrm{MPa}$ while highest was observed for $30 \%$ binder, and at 200 $\mathrm{MPa}$. The relaxed density is the density of the briquette measured after certain period of time i.e., after endured stability. From figure 4, it can be seen that the relaxed density of briquettes is lower than the compressed density. The relaxed density of briquettes produced at 0 and $30 \%$ of binder proportions are more than that of briquettes produced at 10 and $20 \%$ binder proportions at all pressures. The relaxed density varies from 947 to $1023 \mathrm{~kg} / \mathrm{m}^{3}$ for $\mathrm{S} 1$, 891 to $948 \mathrm{~kg} / \mathrm{m}^{3}$ for $\mathrm{S} 2,885$ to $983 \mathrm{~kg} / \mathrm{m}^{3}$ for $\mathrm{S} 3$, while 991 to $1022 \mathrm{~kg} / \mathrm{m}^{3}$ for $\mathrm{S} 4$. The highest relaxed density 1023 $\mathrm{kg} / \mathrm{m}^{3}$ was observed at the $0 \%$ binder (S1) proportions, 200 MPa while the lowest $885 \mathrm{~kg} / \mathrm{m}^{3}$ was observed at $20 \%$ 

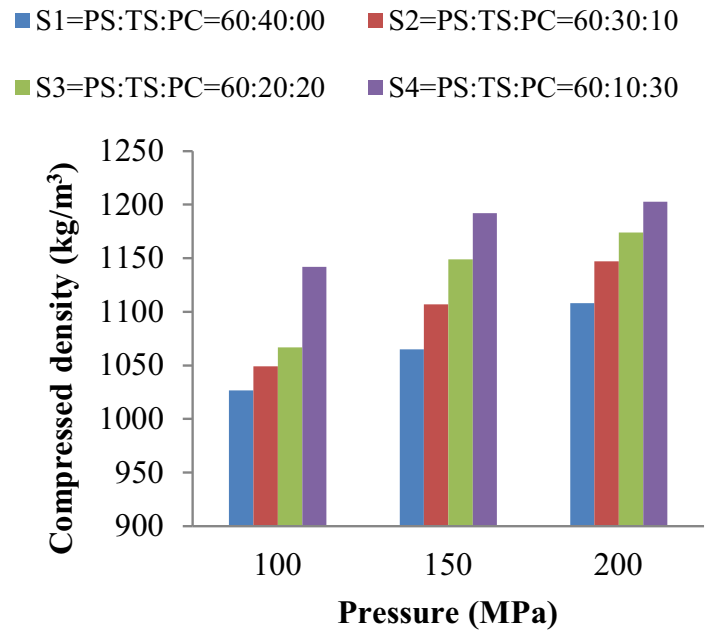

Figure 3. Effect of pressure on compressed density of briquettes at different binder proportions (values represent the average of the results obtained from three independent experiments).
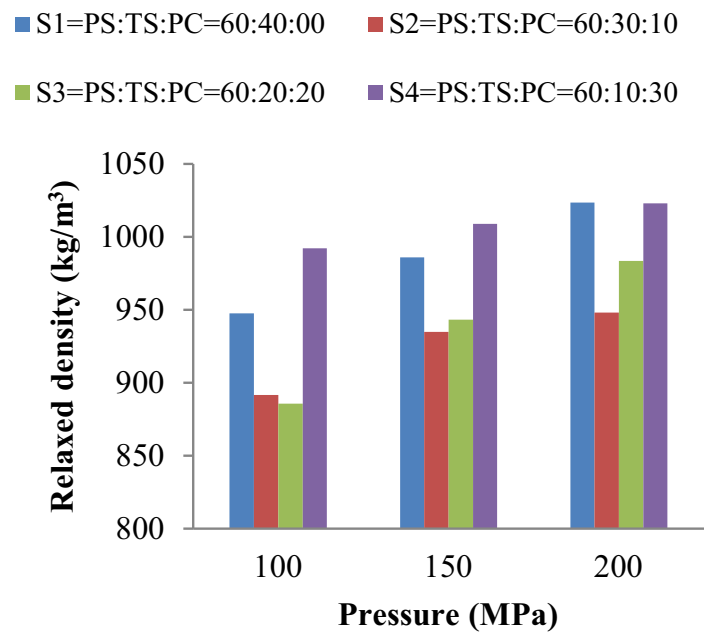

Figure 4. Effect of pressure on relaxed density of briquettes at different binder proportions (values represent the average of the results obtained from three independent experiments).

binder (S3) proportions, $100 \mathrm{MPa}$. According to Eriksson and Prior [17], most technological processes produce briquettes with densities above $1000 \mathrm{~kg} / \mathrm{m}^{3}$ and the physical upper density limit for ligno-cellulosic material is about $1500 \mathrm{~kg} / \mathrm{m}^{3}$. The produced briquettes with highest relaxed density $1023 \mathrm{~kg} / \mathrm{m}^{3}$ (S1 at $200 \mathrm{MPa}$ ) fall within the acceptable range of above $1000 \mathrm{~kg} / \mathrm{m}^{3}$ and have the required strength to withstand handling, transportation and storage. Relaxation ratio is an important parameter to indentify the stability of the briquette. The increase in the relaxation ratio of the briquettes decreases the stability of the briquettes after ejection from the mould [18]. In figure 5 , it is showed that as the percentage of binder (PC) was increased from 0 to $20 \%$ there were a consecutive increase
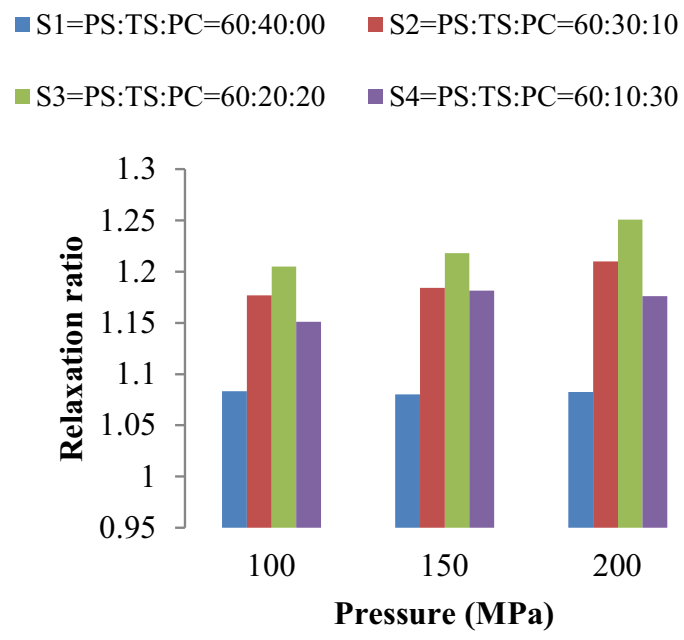

Figure 5. Effect of pressure on relaxation ratio of briquettes at different binder proportions (values represent the average of the results obtained from three independent experiments).
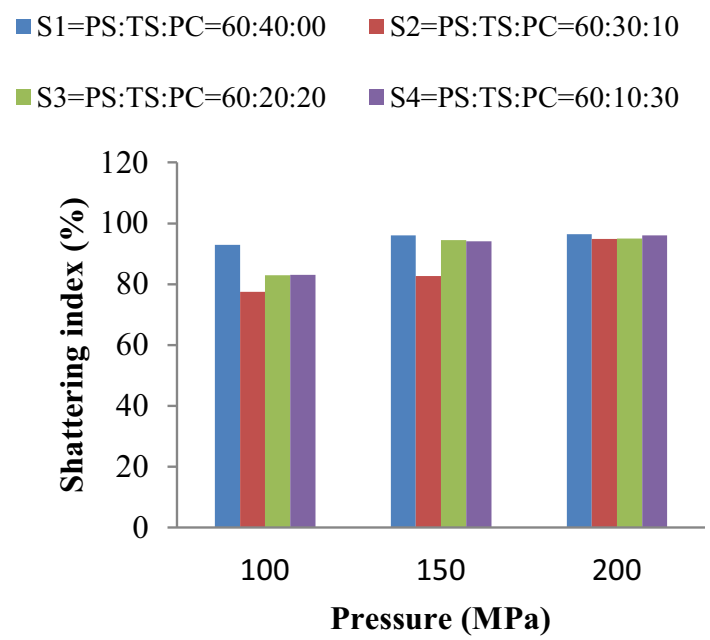

Figure 6. Effect of pressure on shattering index of briquettes at different binder proportions (values represent averages of the results obtained from three independent experiments).

in the relaxation ratio at all pressures. Further, when the binder proportions were increased from 20 to $30 \%$ there was a decrease in the relaxation ratio, which was less than that of S2, S3 and greater than that of S1. The highest relaxation ratio of 1.25 was observed for $\mathrm{S} 3,200 \mathrm{MPa}$ while the lowest of 1.08 was observed for $\mathrm{S} 1$ at all presures. The current results suggested that the briquettes produced without pongamia cake (S1) have had better stability than briquettes produced with pongamia cake (S2, S3, S4). In addition, compressed density, relaxed density and relaxation ratio values of briquettes obtained for S1 at $200 \mathrm{MPa}$ were superior when compared to the respective parameter values obtained for sawdust briquettes and water lettuce briquettes reported $[18,19]$. 
Shattering index is a parameter which indicates the quality of briquette, i.e., the ability to produce fewer fines during handling. The higher the value of shattering index, better the quality of briquette. Figure 6 describes the relatioship between the shattering index and pressure for different samples. As can be seen from the figure, the shattering indices of briquettes produced without binder (S1) at all pressures were larger than other three samples (S2, S3, S4) which used binder percentage as 10, 20, 30\% for S2, S3, S4 respectively. It can also be seen from figure 6 , as the pressure increased, the shattering index increased for all samples. However, as the binder percentage increased, the shattering index increased for S2, S3 and S4. The highest shattering index of $96.42 \%$ was obtained for S1, $200 \mathrm{MPa}$ while lowest of $77.52 \%$ was obtained for S2, $100 \mathrm{MPa}$. According to Moses and Augustina [19], the briquettes with a value of shattering index equal or above 95\% fall within the acceptable range. At $100 \mathrm{MPa}$ sample without binder (S1) showed an increased shattering index compared to those samples with varying amounts of binder (S2-S4). Our results showed that the briquettes produced without binder have had highest shattering index (96.42\%) at $200 \mathrm{MPa}$ and this value fall within the acceptable range according to aforementioned standard. Hence this research concludes that the use of pongamia cake as a binder for the production of briquettes at low pressure is not recommended.

Figure 7 describes the relatioship between compressive strength and pressure for different samples. The higher the value of compressive strength, better the quality of briquette. As the pressure increased the compressive strength of the briquettes increased. Compressive strength of briquettes for S1 increased significantly with increase in pressure as compared to other samples. Further, results indicated that compressive strength of briquettes for S2, S3 and S4 were not increased significantly even with increase
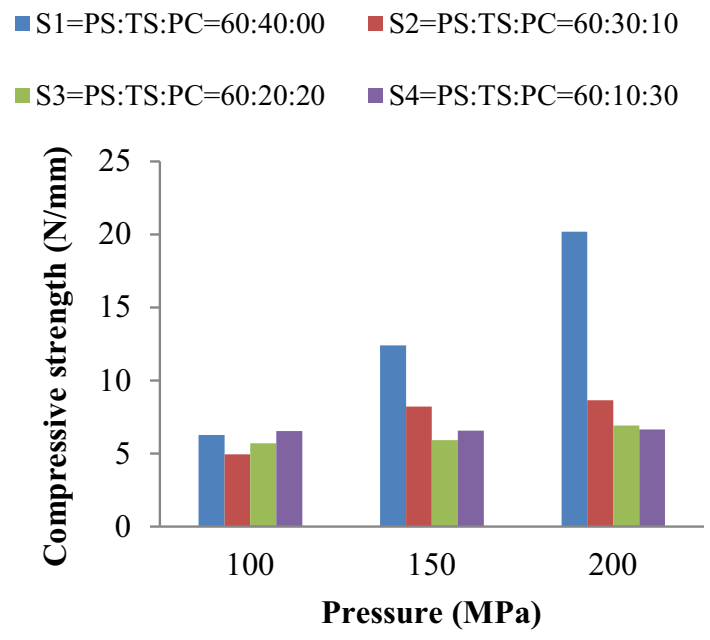

Figure 7. Effect of pressure on compressive strength of briquettes at different binder proportions (Values represent the average of the results obtained from three independent experiments). in pressure. The compressive strength varies from 6.26 to $20.18 \mathrm{~N} / \mathrm{mm}$ for S1, 4.94 to $8.64 \mathrm{~N} / \mathrm{mm}$ for S2, 5.69 to 6.91 $\mathrm{N} / \mathrm{mm}$ for S3, while 6.53 to $6.63 \mathrm{~N} / \mathrm{mm}$ for S4. The highest compressive strength of $20.18 \mathrm{~N} / \mathrm{mm}$ was observed for S1 at $200 \mathrm{MPa}$ and lowest of $4.94 \mathrm{~N} / \mathrm{mm}$ was observed for S2 at $100 \mathrm{MPa}$. Thus this research work confirms that, the use of pongamia cake for the production of briquettes created adverse effect on compressive strength of briquettes and hence, it is not recommended. According to Rahman et al [20], the briquettes surface compressive strength of 19.6 $\mathrm{N} / \mathrm{mm}$ is reasonably adequate for handling or can be used as fuel for domestic purposes. S1 briquettes produced in our study have had adequate compressive strength at $200 \mathrm{MPa}$ in cleft of instron universal strength testing machine and were considered suitable for handling $(>19.6 \mathrm{~N} / \mathrm{mm})$. Compressive strength of briquettes obtained from our study were comparable to the compressive strength of Piptadenia africana briquette obtained by Mitchual et al [21].

From the above discussion it can be concluded that, sample S1 (i.e., with a proportion of PS:TS:PC $=60: 40: 00$ ) at $200 \mathrm{MPa}$ has superior briquette properties compared to all other samples (S2, S3 and S4) and met with the briquette standards. Thus, the proximate analysis, the ultimate analysis and the calorific value were conducted for the S1 sample at $200 \mathrm{MPa}$.

\subsection{Combustion characteristics of briquettes}

Combustion characteristics such as the proximate analysis, the ultimate analysis and the calorific value were estimated for Pongamia-Tamarind briquettes and compared with

Table 2. Proximate and ultimate analysis of agro waste briquette and Pongamia-Tamarind shell briquette.

\begin{tabular}{|c|c|c|}
\hline Property & $\begin{array}{c}\text { Agro waste } \\
\text { briquette [22] }\end{array}$ & $\begin{array}{l}\text { Pongamia-Tamarind shell } \\
\text { briquette }^{\mathrm{a}} \text { (PS:TS:PC = } \\
60: 40: 00)\end{array}$ \\
\hline \multicolumn{3}{|c|}{ Proximate analysis (on as received basis, wt.\%) } \\
\hline Moisture & 10.1 & 5.03 \\
\hline $\begin{array}{l}\text { Volatile } \\
\text { matter }\end{array}$ & 79.3 & 76.86 \\
\hline $\begin{array}{l}\text { Fixed } \\
\quad \text { carbon }\end{array}$ & 4.1 & 15.40 \\
\hline Ash & 6.5 & 2.71 \\
\hline \multicolumn{3}{|c|}{ Ultimate analysis (on dry and ash-free basis, wt.\%) } \\
\hline $\mathrm{C}$ & 44.7 & 65.79 \\
\hline $\mathrm{H}$ & 3.43 & 7.06 \\
\hline $\mathrm{N}$ & 0.81 & 0.56 \\
\hline $\mathrm{O}$ & 44.2 & 18.67 \\
\hline $\mathrm{S}$ & 0.30 & 0.18 \\
\hline $\begin{array}{l}\text { Calorific } \\
\text { value } \\
(\mathrm{MJ} / \mathrm{kg})\end{array}$ & 12.2 & 16.74 \\
\hline
\end{tabular}

${ }^{a}$ Present study 
current briquette raw materials (Pongamia and tamarind shell as shown in table 1) and agro waste briquettes (table 2).

The results in table 2 indicated that Pongamia-Tamarind shell briquettes had lower moisture and ash content than briquette raw materials (table 1) and agro waste briquettes. Since the volatile matter of Pongamia-Tamarind shell briquettes is more than that of briquette raw materials (table 1), it can easily ignite and burn. The percentage of fixed carbon present in the briquettes is a critical factor in determining the calorific value of fuel [23]. As the fixed carbon percentage of the Pongamia-Tamarind briquette is more than that of agro waste briquette, the calorific value is higher than that of agro waste briquette.

A significant characteristic of any fuel is its calorific value and it is the amount of heating value contained in fuel per unit volume. Briquetting process does not add to the calorific value of the base biomass [24]. The calorific value of briquette raw materials and that of Pongamia-Tamarind shell briquette were very close to each other and it has been proven.

Greater the percentage of carbon and hydrogen, better the quality of fuel. From table 2 it is observed that the carbon and hydrogen percentage of Pongamia-Tamarind shell briquettes are higher compared to both agro waste briquette and briquette raw materials (table 1). According to Jittabut [25], it is recommended that the sulphur and nitrogen content in fuel should be less than $1 \%$ as it minimizes the polluting effect of the briquettes. As mentioned in material selection, one of the reasons for blending the PS, PC with TS is to neutralize the effect of nitrogen in the briquette and it has been achieved. High oxygen content in the fuel is characterized by high innate moisture content. Oxygen combines with hydrogen to form water vapour which decreases the availability of hydrogen for combustion which results in decrease in calorific value and quality of the fuel. Our results showed that amount of oxygen is less in Pongamia-Tamarind shell briquette than that of briquette raw materials and agro waste briquettes.

\section{Conclusion}

The results of this research work indicated that pongamia shell and tamarind shell can be used for the production of better quality briquettes and these are potentially available raw materials. Also, this work suggests that the use of pongamia cake as an additive for the production of briquettes creates an adverse effect on the properties of briquettes and thus, it is not recommended. The briquettes produced at a pressure of $200 \mathrm{MPa}$ with a blending proportion of PS:TS $=60: 40$ have better combustion characteristics than that of individual raw materials. These briquettes can be used for steam generation and several heating applications. Based on the ultimate analysis of
Pongamia-Tamarind shell briquette, it can be concluded that compared to raw agro waste, the nitrogen and sulphur content is low and hence the $\mathrm{NO}_{\mathrm{X}}$ and $\mathrm{SO}_{2}$ emissions would be lower. Further, when compared to coal any agro fuel is carbon neutral.

\section{References}

[1] Osvalda S 2011 Characterization of Biomass as Non Conventional Fuels by Thermal Techniques, Progress in biomass and bioenergy production, S Shahid Shaukat, Croatia, InTech, pp. 299-324

[2] Moral M N A, Shakya G R and Toan P K 2005 Technology Packages: Screw-press briquetting machines and briquettefired stoves, S C Bhattacharya and S Kumar (eds.), Thailand, Regional Energy Resources Information Center (RERIC), pp. $1-76$

[3] Branca G, Cacchiarelli L, Cardona C A, Felix E, Gianvenuti A, Kojakovic A, Maltsoglou I, Martchamadol J, Rincon L, Rossi A, Seghetti A, Steierer F, Thofern H, Thulstrup A, Tolli M, Valencia M and Valle S 2014 Bioenergy and food security rapid appraisal (BEFS RA) briquettes user manual, Food Agriculture organization of the united nations (FAO), Italy, pp. 1-44

[4] Lohan S K, Ram T, Mukesh S, Ali M and Arya S 2013 Sustainability of biodiesel production as vehicular fuel in Indian perspective. Renew. Sust. Energy Rev. 25: 251-259

[5] Cardoen D, Joshi P, Diels L, Sarma PM and Pant D 2015 Agriculture biomass in India: Part 1. Estimation and characterization. Resour. Conserv. Recycl. 102: 39-48

[6] Borugadda V B and Goud V V 2012 Biodiesel production from renewable feedstocks: Status and opportunities. Renew. Sust. Energy Rev. 16(7): 4763-4784

[7] Saxena M, Bhattacharya S and Malhotra S K 2015 Overview, Horticultural Statistics at a Glance, India: Oxford University Press, pp. 8-21

[8] Demirbas A 2004 Combustion characteristics of different biomass fuels. Prog. Energy Combust. Sci. 30(2): 219-230

[9] Prasad L, Subbarao P M V and Subrahmanyam J P 2015 Experimental investigation on gasification characteristic of high lignin biomass (Pongamia shells). Renew. Energy 80: 415-423

[10] Mythili R, Venkatachalam P, Subramanian P and Uma D 2013 Characterization of bioresidues for bio-oil production through pyrolysis. Bioresour. Technol. 138: 71-78

[11] Prasad L, Subbarao P M V and Subrahmanyam J P 2014 Pyrolysis and gasification characteristics of Pongamia residue (de-oiled cake) using thermogravimetry and downdraft gasifier. Appl. Therm. Eng. 63: 379-386

[12] Obi O F, Akubuo C O and Okonkwo W I 2013 Development of an appropriate briquetting machine for use in rural communities. International Journal of Engineering and Advanced Technology (IJEAT) 2(4): 578-582

[13] ISO: International standard ISO 31311975 Standard test method for density of regular Solids, Geneva

[14] American Society for Testing and Materials (ASTM. D44086) 1998 Standard test method of drop shatter test for coal. West Conshohocken 
[15] American Society for Testing and Materials (ASTM D216685) 2008 Standard test method of compressive strength of wood, West Conshohocken

[16] Indian Standard:1350 (Part-I, 1984), (Part-III, 1969), (PartIV/Sec1, 1974), (Part-IV/Sec 2,1975), (Part-II, 1970) Standard test method for proximate analysis, ultimate analysis and calorific value for coal and coke

[17] Eriksson S and Prior M 1990 The briquetting of agricultural wastes for fuel. FAO Environment and Energy, pp. 11-131

[18] Obi O F 2015 Evaluation of the effect of palm oil mill sludge on the properties of sawdust briquette. Renew. Sust. Energy Rev. 52: 1749-1758

[19] Moses D R and Augustina D O 2014 Some physical and mechanical properties of water lettuce (Pistia stratiotes) briquettes. Am. J. Sci. Technol. 1(5): 238-244

[20] Rahman A N E, Aziz M M, Prasad C S N and Venkatesham M 1989 Influence of size and shape on the strength of briquettes. Fuel Process. Technol. 23: 185-195
[21] Mitchual S J, Frimpong-Mensah K and Darkwa N A 2013 Effect of species, particle size and compacting pressure on relaxed density and compressive strength of fuel briquettes. Int. J. Energy Environ. Eng. (IJEEE) 4: 30

[22] Liu Y, Wang X, Xiong Y, Tan H and Niu Y 2014 Study of briquetted biomass co-firing mode in power plants. Appl. Therm. Eng. 63: 266-271

[23] Thabuot M, Pagketanang T, Panyacharoen K, Mongkuta P and Wongwicha $\mathrm{P} 2015$ Effect of applied pressure and binder proportion on the fuel properties of holey bio-briquettes. Energy Procedia 79: 890-895

[24] Antwi-Boasiako C and Acheampong B B 2016 Strength properties and calorific values of sawdust-briquettes as wood-residue energy generation source from tropical hardwoods of different densities. Biomass Bioenergy 85: 144-152

[25] Jittabut P 2015 Physical and thermal properties of briquette fuels from rice straw and sugarcane leaves by mixing molasses. Energy Proc. 79: 2-9 